How to Cite:

Sondakh, D. S. I., Rahmatullah, A. S., Adiyono, A., Hamzah, M. Z., Riwayatiningsih, R., \& Kholifah, N. (2022). Integration of language, psychology, and technology and the concept of independence learning in reading characters in indonesian children's films as media and learning materials in character building for elementary school students-

indonesia. Linguistics and Culture Review, 6(1), 70-88.

https://doi.org/10.21744/lingcure.v6n1.1963

\title{
Integration of Language, Psychology, and Technology and the Concept of Independence Learning in Reading Characters in Indonesian Children's Films as Media and Learning Materials in Character Building for Elementary School Students-Indonesia
}

\section{Daniel Stefanus Imanuel Sondakh}

Christian University of Indonesia, Tomohon, Indonesia

Azam Syukur Rahmatullah

Universitas Muhammadiyah Yogyakarta, Indonesia

\section{Adiyono}

Sekolah Tinggi Ilmu Tarbiyah (Ibnu Rusyd), Tanah Grogot, Indonesia

Muh. Zuhdy Hamzah

UIN Maulana Malik Ibrahim, Malang, Indonesia

\section{Rika Riwayatiningsih}

Universitas Nusantara PGRI Kediri, Indonesia

Nanik Kholifah

Universitas Yudharta Pasuruan, Indonesia

\begin{abstract}
The purpose of this research is to integrate psychology, technology, and language in reading the characters in Indonesian children's films as media and learning materials for character building for elementary school students in Indonesia. This research design uses mixed methods. The source of research data is sourced from elementary school students' learning activities in Indonesian subjects using Indonesian children's films as media and learning materials. Data were collected using questionnaires, interviews, and focus group discussions. Respondents of this study were elementary school teachers as many as 98 teachers. Qualitative data were analyzed by interpreting techniques
\end{abstract}


and presented in the form of descriptions, while quantitative data were analyzed by calculating the average student learning outcomes presented in the form of percentages. The findings of this study are twofold, namely, the findings of this study are twofold, namely by using Indonesian children's films as a medium as well as a source of learning and learning materials can shape students' character and improve student achievement.

Keywords---film, independence learning, learning, media, psychotechnoliteracy.

\section{Introduction}

Learning is a complex series of activities that include learning, teaching, and being supported by subject matter as a source of learning and media as teaching aids or intermediaries that facilitate the continuity of the learning process. Learning and teaching each has a principal. Students who are taught and teachers who teach. Both are mutually integrated in teaching activities. Likewise with the subject matter and media. To make it easier for the subject matter to be accepted and understood by students, it requires media as a means of support. Therefore, both of them are integrated in the knowledge transformation process carried out by teachers and students.

Non-formal learning has a broad understanding. Learning can lead to all aspects. In fact, all the processes that are passed in life in all human activities are learning. Simplified, learning is a process of interaction, adaptation, and the process of exchanging information. The process of communicating too, both interpersonally and in a group is part of the learning process. However, if learning is viewed in a formal aspect, then learning is identical to the teaching process.

Teaching is part of learning activities. However, both have concrete definitions. Learning is related to learning activities. Learning is related to psychology as an independent science. The subject of learning has even become the most studied topic in the field of psychology. In fact, the definition of learning can be found in various fields of science. This shows that the definition of learning is very diverse across disciplines. The definitions of learning across various disciplines can be combined and reconciled between one discipline and another (Ebbinghaus, 2013; Thorndike, 1911; De Houwer et al, 2013, Barron et al, 2015). Abbott (1994), learning is a series of activities that encourage students to reflect on themselves by utilizing their knowledge and experience in the learning process to form new knowledge. Lachman (1997), learning refers to learning activities which include the process of changing behavior based on experience. Thus, learning is the effect of experience on behavior.

Learning and knowledge are two important things and are interrelated. Learning is a process of transforming and acquiring knowledge. Meanwhile, knowledge can be built through learning. This is in line with the goal of the explanation put forward by Jarvis (2007), that learning and knowledge are considered as fundamental resources for future development. Knowledge can be acquired in lifelong or lifelong 
learning. With knowledge, humans can compete in global competition. Becker (2009); Mincer (1958), argue that since the beginning of the 20th century by some parts of the Western world, learning has revolutionized learning as part of education that requires people to get a proper education through institutions both formal and informal. non-formal.

Van Rossum \& Hamer (2010), put forward the definition of learning which is summarized into several concepts. First, learning is a process of increasing knowledge. Second, learning is the process of reciting and memorizing material. Third, learning is the process of acquiring facts, procedures, and others. Fourth, learning is an abstraction of meaning. Fifth, learning is an interpreting process that refers to an understanding of reality. Sixth, learning is a process of self-realization. Referring to the summarized concepts, the essence of learning, whether defined based on formal or non-formal education, is the process of acquiring knowledge that can be used as a reference in changing mindsets and attitudes or behavior so that it is more humane. That is, learning is a more complex human process, although in reality no human is perfect.

Meanwhile, the teaching process is the act of teaching or teaching which is related to the process of interaction between students as people who learn and teachers as people who teach. Students as people who learn have the potential to become useful human beings. Psychologically, all humans have various potentials and need to be developed through various activities. The potential of students can be developed through learning activities that are supported by the teacher. Therefore, teachers must be educated. That is, educated teachers are not only supported by the ability to interact with students as social beings. However, teachers must also have adequate knowledge, sufficient experience, unquestionable competence, and most importantly, exemplary behavior. Because, as one of the goals of teaching as part of the learning process is the process of changing behavior or attitudes.

Many experts in education or teaching are familiar in this world. Of course, they also have different definitions of teaching based on their approach, experience, and perspective. Nilsen \& Albertalli (2002), focusing on the teaching process are teaching activities carried out by teachers. Teaching refers to the teacher guiding a student or group of students from a low level of knowledge and skills to a higher level. On the other hand, Desforges (1995), argues, teaching is part of the process of managing student experiences which is mostly carried out in the classroom or at school as a strategy in teaching students.

Teaching is a teaching process carried out by teachers to teach students. Teaching is an effective process in learning. Teaching is the responsibility of a teacher in carrying out active and effective learning. Teaching is an ethical task or activity that must be carried out in learning. Teaching as a process of facilitating learning. Teaching as a process carried out by teachers in imparting knowledge, transferring skills, simulating attitudes, and applying values to students. In addition, teaching as a process of integrating the intellectual and capacities of students to change student behavior. Thus, the teaching process is not only aimed at conveying information to students, but also regarding how to receive, integrate, and apply the information conveyed by the teacher (Etsey et al., 2009; Farrant, 1980). 
Teaching is a teaching activity as part of the arts that aims to motivate students to behave according to learning outcomes. In fact, persuading students to apply the acquired behavioral concepts into their daily social activities. because, basically changing a more positive behavior is one of the important goals in learning. Teaching as an art with respect to teachers must have special skills in creating a more comfortable and enjoyable learning situation. In addition, teachers must also have strategies and approaches in motivating students to have a higher interest in learning (Schlechty, 2004).

Regarding teaching, Melby (1994), also states that teaching is not just about channeling and transferring lessons. However, teachers must be able to involve students in the teaching and learning process. In this case, students are given the opportunity to participate fully, namely students become the main actors in teaching and learning activities. Meanwhile, the teacher, in addition to acting as a facilitator, also acts as a director, mentor, and evaluator. Therefore, the teacher as a teacher, then he must be open to accept every difference that is owned by each student. Students as people who want to learn and have potential must be treated in the same way, equitably, and fairly. This is to avoid a sarcastic impression that can lead to ridicule so that there are irregularities and negative deviations for the community aimed at teachers.

It is different from Thring's (2001), point of view in defining teaching. According to him, teaching as part of the teaching process is not only limited to the process of pouring lessons or transferring knowledge to students. However, teaching is essentially related to the ability of the teacher to get the hearts and minds of students to awaken and give confidence to students' understanding that teaching and learning is a valuable thing and the process must be followed.

Based on the different definitions of teaching put forward, Van Rossum \& Hamer (2010), summarize the definition of teaching in several concepts. First, teaching is the process of transforming clear and structured information. Second, teaching is the process of transmitting knowledge in a structured manner so that it can be accepted and understood by the recipient. Third, teaching is a process of interaction and character formation. Fourth, teaching is a challenging process to think for yourself and develop a way of thinking. Fifth, teaching is a process of dialogue and communication. Sixth, teaching is the process of building a system of authentic trust and relationships or caring for each other.

Many things can be done by teachers to make it easier for the subject matter to be understood and accepted by students in the learning process. One of them, using the media as an intermediary. Media has an important role in connecting students with the subject matter. Media can be used as a solution in solving problems found by teachers in the learning or teaching process. Media can also be interpreted as a communication device. This is alluded to by Dewney \& Ride (2006); Flew (2007); Heinich (1996), the media is a communication channel. Media or medium comes from Latin which means "between" or "intermediary". The term relates to the media as an intermediary in conveying information carried out by the speaker to the recipient. The media concept focuses on technology. Therefore, in learning, the media acts as a means to send messages (deliver material). 
By using media, it can motivate students to be actively involved in the learning process. The most important thing in using media is to be able to make communication effective. Therefore, if a media is designed properly and optimally, it will have a drastic effect on teaching or learning activities. The influence or positive impact on the use of learning media, among others; saving time; increase student interest in learning; invite students' attention to the material; clarify the idea of the material section; strengthen concepts related to the material; facilitate the teacher in delivering the material; provide deeper knowledge to students; and provide learning experiences to students Mohan et al. (1992).

Media can also be defined as a learning and teaching device. media related to technology, symbol systems, or things that are considered to facilitate the learning process (Kozma, 1991). Learning media can provoke students to study independently and in groups without expecting full teacher involvement. This is because the media is not only an intermediary for communication, but even the media can be a set of tools that include teaching materials or materials so that they can directly educate students. Good media are media that can make learning more interesting and create a comfortable-fun learning atmosphere so that the learning process becomes effective, both in the classroom and outside the classroom or outside the school environment (Locatis \& Atkinson, 1990).

From the 1980 s to the 2000 s, it was known as the millennial era, namely life that cannot be separated and avoided from the help of information technology. The millennial era is also called the era of disruption or the era of disruption. The era of disruption is a phenomenon that encourages people to move through the virtual world which previously went through the real world. That is, the era of disruption is an era of technological development that is growing rapidly and sophisticatedly so that almost all daily activities carried out by people in their lives cannot be separated from the help of technology or digital-based media. Therefore, the era of disruption is also called the digital era.

Sivitanides \& Shah (2011), argues that the digital era is a digital revolution movement. The digital revolution is as if everyone is invited to enter a new world by introducing new things. This is regarding that almost all activities are processed digitally. With another explanation, that the digital era makes human life more modern, namely shifting from activities that were originally still traditional to new activities due to the various sophisticated and more modern facilities offered. This statement shows that the digital era as it is today, like it or not, everyone in all corners of the world must accept the presence of the digital era as a real thing and has been confronted, and even some people from around the world have enjoyed and used the facilities offered.

Gallardo-Echenique et al. (2015), estimates that digital technology was born between 1980 and 1994. The emergence of the digital era encourages teachers and students to be more creative and skilled in the learning process. Based on the conclusions of research conducted by Yasumuto (2014), it shows that learning using digital-based media attracts the interest of many academics, especially teachers. Apart from being a liaison between subject matter and students, digitalbased media can also optimize student learning activities. Digital-based media can be applied directly and also indirectly (two-way) or distance learning. Thus, 
learning using digital-based media has been implemented by educational institutions in Japan.

In line with the development of advanced technology which is marked by the widespread use of digital-based media, the types of learning media are also developing. Based on the type, there are three types of learning media, namely audio-based media, visual-based media, and audio-visual-based media. First, audio-based media is media that can display sound or supported media and has sound elements so that it can be heard directly by students. Audio-based media is a type of media that contains messages in an auditive form that can stimulate students' feelings, attention, and abilities in learning and understanding the subject matter.

Second, visual-based media are media that can be sensed directly by students through the sense of sight. Visual-based media can react to students so that students can easily describe concepts through visualized media. In addition, visual media or visual-based media can facilitate student understanding while strengthening student memory. This is because, what is seen directly by students can be observed properly to form a knowledge structure which is then collaborated between previous knowledge and new knowledge found and finally a concept is formed. Forms of visual-based media in the form of images, paintings, or photos, and the like (Hamidi et al., 2011; Diergarten et al., 2017).

Third, audio-visual-based media is media that combines two elements, namely elements of sound that can be heard and elements of images that can be seen. The use of audio-visual-based media in learning will motivate students to learn more actively. In the learning process, students will involve their senses of hearing and sight in turn in receiving, processing, and integrating the messages or subject matter presented. Audio-visual-based media, in addition to provoking students to observe and understand the concept or material, students also feel given a stimulus to simulate the material understood in the form of motion.

Audio-visual-based media are more complex and effective in their use in learning when compared to audio-visual-based media only. That is, audio-visual-based media has more advantages and advantages compared to audio-visual-based media. This can be proven based on the results of research conducted by Gonçalves et al. (2017). Achievements and research results show that by using audio-visual-based learning media, the average student gets a score of 85.833 which indicates success in learning reaches 95\%, while using audio-based and visual-based learning media, the average student scores 79,500. . Thus, it can be concluded that audio-visual-based learning media can have a significant influence on student achievement and learning outcomes.

One variety of audio-visual-based media that can be used in learning is a film that can be shown using a rich screen or television. In addition to the film can be visualized through images or motion that is shown live, it can also produce audio so that it can also be heard directly. Films can be used as media as well as teaching materials for students. Champoux (2001), suggests, film can be categorized as an audio-visual communication tool. Films can improve the learning 
process with the uniqueness and facilities that exist and are not available in other media.

Film is a product and medium of culture as well as art. In addition, films can also be called imaginative works because part of what is shown is based on the reality of human life which is shown fictionally by changing some of the settings and changing the names of the actors. Film as a cultural medium because not a few films are found to represent a certain culture. Furthermore, film is an art because the creation process until everything that is shown in a film scene requires a creative process and expression. In fact, movie stars are seen as "cultural icons" (Marsh \& Ortiz, 1997). Film-related to art and culture, also emphasized by Corrigan \& White (2012), that film as a literary work is rich with cultural practices that are shown. The strength of film as an art because it depicts the creative process that is combined between factual and fictitious things. Factual deals with reality, while fiction deals with fantasy. Thus, in general, films as a means of entertainment.

The advantages and advantages of film so that it can be used as a medium, as well as subject matter for students, are based on the two essences of film proposed by Arnheim (1957). First, films record physical reality or produce reality mechanically. Second, film also resembles painting, music, and literature. In other words, that film is a complex work because it can display various things, both relating to images such as paintings, producing sound through music that is played, and aspects related to literature, namely storylines contained in works of fiction, and then filmed.

Film in human life has many functions. Especially in teaching and learning activities. The use of film as a medium in learning can improve students' literacy and cognitive skills. First, literacy skills can be realized by students through the process of decoding, interpreting, and finding impressions to create messages from the reading process that students do on all things that are shown, both in the form of actions and implied and explicit context meanings in the film (Dorr \& Brannon, 1992; Giroux \& Simon, 1989; Sizer, 1992; Hobbs, 1998).

The decoding process in question refers to the process of understanding and interpreting students' visual codes that contain aspects of imagination. Meanwhile, the purpose of the message made is based on students' understanding of the motion or images that are displayed. The process is not only limited to understanding and interpreting but can be identified through language, namely the ability to retell or represent the image that is listened to using one's own words through language as the medium (Greenfield, 2014).

Second, cognitive skills can be realized through students' ability to think critically and creatively. Critical thinking is the ability to respond to a concept through an analytical, structured, and systematic thinking process. Creative thinking is a process involving the brain in processing and integrating some information so as to obtain new ideas. Lau \& Chan (2004); Nimalathasan \& Valeriu (2010), creative thinking and critical thinking are two things that sometimes cannot be separated. Both are related in the thought process. Critical thinking is the ability to think clearly and rationally about something so that the results can be accepted and 
trusted. Critical thinking is an important part of creative thinking. Because people need critical thinking to evaluate and improve their creative ideas.

Furthermore, new ideas that are considered relevant and can be used as solutions in solving a problem are the result of a creative thinking process. Critical thinking plays an important role in evaluating new ideas (Paul \& Elder, 2011). In general, critical thinking is correlated with creative thinking. Critical thinking involves the power of analytical and review processes to obtain a higher level of belief in something, while creative thinking involves the power of imagination so as to obtain innovative new thoughts or ideas (Aslan, 2010; Rhodes, 1961; Sternberg, 2009).

Based on the previous explanation, it can be concluded that films can play a role in the learning process. In this case, that film can not only be used as a medium or intermediary in conveying material but films can be used as a source of learning as well as subject matter through a series of stories presented. Because basically, the series of stories presented in a film are not much different from the stories presented in fiction. The stories presented are more representative of the reality of life and provide benefits. Not only that, but most of the stories represented have high values that can be used as life lessons, even in the world of education, they can be used as learning for students' character formation (Plass \& Kaplan, 2016; Dehkordi, 2011).

Indonesian children's films are films that are more dominantly played by children and the aim is also for children, even though in reality they are also widely liked by adults or the general public. Indonesian children's films not only represent the social life of the general public, but also represent more specific matters such as culture and present interesting and uplifting themes. Therefore, based on the initial observations made by the researcher, in addition to Indonesian children's films, they can be used as media, but also as a source of learning or learning materials for the formation of student character. Things that can be learned from Indonesian children's films include the characters of the actors or characters, either through expressions or expressions, behavior, and or through words, sentences, or fragments of expressions spoken directly by the actors.

Some experts have given the basic understanding and concept of character etymologically. First, Ryan \& Bohlin (1999), the word "character" in English is called "character", while in Greek it is called "charassein" which means "to engrave". Second, Echols \& Shadily (1995), the word "to engrave" refers to the meaning of "to engrave". The word "engraving" can be expanded its meaning into a painting of the soul or a depiction of the soul embodied in behavior. In other words, carving out a distinctive behavior based on the soul by referring to the norms or orders that apply in life.

Character is about morals. In general, character is the tendency of the soul and heart to always behave gently and commendably (Al Hamdani, 2016). In addition to the character regarding the nature of character that must be possessed by every human being from birth or childhood as suggested by some experts in religious psychology, but in fact, character can also be built and formed when he is an adult. By elaborating several expert opinions, character is a personality that is manifested through commendable behavior or actions and words that provide 
benefits, both for oneself and for others. In addition, the character is basically a set of attitudes or traits that can be formed through various activities and intermediaries, such as the interaction process in social life and or the communication process in discussion activities. Especially in the world of education, character can be formed and built in the learning process through films as a medium as well as a source of learning and learning materials.

The essence of psychotechnoliteracy that is used as a benchmark in this research is to integrate three disciplines, namely psychology, technology, and language. First, the concepts of character are an elaboration of the role of the discipline of psychology in studying matters relating to psychology in general. Second, the concepts of media and film are an elaboration of the role of technological disciplines in studying and strengthening the role of film as a medium and source of learning or learning materials. Third, concepts related to literacy and cognitive skills are the elaboration of the role of linguistic disciplines in improving students' reading skills related to creative and critical thinking processes (Siekanska et al., 2021; Ahmad, 2012). Therefore, the framework for this research is presented as shown in the following figure.

\section{Method}

This research design uses mixed methods. Creswell \& Clark (2017), argues, mixed methods is an internal approach by combining qualitative and quantitative research. The source of research data is sourced from elementary school students' learning activities in Indonesian subjects using Indonesian children's films as media and learning materials. Research data consists of two types, namely qualitative and quantitative data. Qualitative data in the form of statements, opinions, and responses about three things. First, the types of characters found in Indonesian children's films. Second, the role of Indonesian children's films as media and learning materials. Third, students' ability to understand the context of the film being shown. The three forms of data are described. Quantitative data is in the form of values in the form of numbers that are concluded based on student learning outcomes obtained and presented in the form of percentages.

The respondents of this study were elementary school teachers. Of the 98 total number of teachers who became respondents, then selected using cluster random sampling technique. Data were collected using questionnaires, interviews, and focus group discussions. The stage of using the questionnaire there are two types of questionnaires. First, a closed questionnaire by asking 30 questions based on the focus of this research. Meanwhile, an open questionnaire was used to collect the teacher's statements, opinions, and responses regarding three things according to the research focus as mentioned above.

Indonesian children's films that are used as media and learning materials are also used as research instruments. The step taken is to direct the teacher to choose several Indonesian children's films that are mostly played by children with interesting and challenging themes for students to watch. The recommended Indonesian children's films include; Petualangan Sherina, Untuk Rena, Serdadu Kumbang, Laskar Pelangi, Tanah Air Beta, Garuda di Dadaku, Denias Senandung di 
Atas Awan, Tendangan dari Langit, Hafalan Shalat Delisa, King, 5 Elang, Kulari ke Pantai, Koki-koki Cilik, dan Keluarga Cemara.

Data collected using a questionnaire, then analyzed through in-depth interviews and focus group discussions (FGD) involving experts in the Indonesian language, language experts in general, teaching materials development team, and several educational psychology experts. Qualitative data were analyzed by interpreting techniques and presented in the form of descriptions, while quantitative data were analyzed by calculating the average student learning outcomes presented in the form of percentages (Tinajero \& Paramo, 1998; Radford et al., 2015).

\section{Result and Discussion}

\section{Types of characters in Indonesian children's films}

In addition to Indonesian children's films, which have binding characteristics, most of them can be used as public spectacle for all age levels. Indonesian children's films do not only describe the social life of society in general. However, it also describes aspects that are specialized in various fields. This is so that it becomes an attraction for the public as consumers or movie lovers. As a medium and source of learning or learning materials, the types of a character cast in Indonesian children's films are explained as follows.

\section{Philanthrope}

Generous is one of the characters with regard to generous nature, likes to share with fellow living beings. In addition, also in religious teachings, generosity can be realized through charity and charity activities. The generous character is represented in the role of Sherina in the film Petualangan Sherina, when Sherina feeds several chicks on a tree branch.

\section{Devoted}

Devotion is one of the characters regarding the nature of being loyal and obedient. Loyalty is a trait that shows a determination to an attitude, is firm and obedient. Meanwhile, submissive nature is a trait that shows a willingness to follow something without various reasons, in this case not fighting as long as what is being followed is related to positive things. The filial character has the goal of being devoted to God as the creator and devoted to parents. Being devoted to parents means having an obedient nature to parents. The character of being devoted to parents is represented by the role of Sherina in the film Petualangan Sherina, when Seherina agrees and agrees to accompany her parents who will move to Bandung because her father was accepted to work in one of the plantations in North Bandung. This gave up Sherina to part with her school friends (Ferdiawan \& Putra, 2013; Sabilah, 2016).

The filial character is also represented by the actor Amek in the film Serdadu Kumbang. Amek, despite having a physical disability in the form of a cleft lip, is always devoted to the people he loves. The form of Amek's worship service is that every time after school, Amek helps her mother and sister sell small items under 
the simple stilt house where they live. The character of filial piety, especially filial piety, is represented by the role of Delisa in the film Memorizing Prayers Delisa, when the actor of Delisa is praying in a state of complete solemnity even though the earthquake and tsunami hit her. The prayer performed by Delisa is a manifestation of her filial character, namely obedience as a servant to her creator.

\section{Patient}

Patience is one of the characters with regard to steadfastness. Resilience can be manifested in a calm attitude. In this case, it is not impetuous, not irritable, and does not like to hold grudges. The patient character is represented by the role of Sherina in the film Petualangan Herina, when Sherian is allowed to meet his new friends at his new school in Bandung after moving from Jakarta. When introducing himself, suddenly one of Sherina's friends badmouthed her by calling her "monkey". However, the slightest hint of Sherina's reaction to retaliate against her friend's pranks.

\section{Cooperate}

Working together is one of the characters that reflects the attitude of living together. Living together is inseparable from the life of every human being as a social being. In another sense, that humans in living their daily lives need the help of others. Working together is more about the attitude of mutual cooperation, compactness, and unity in doing something. The characters working together are represented by the main character consisting of 5 children in the film Lima Elang, when the main characters work together and win one of the competitions held at a camp event in order to fill the school holidays. In addition, the character of working together is also represented by the actor Bayu in the film Garuda di Dadaku, when he is able to mobilize and motivate his friends to fight and try to train to win soccer matches (Nasution, 2018; Azzajjad et al., 2021).

\section{Helper}

Helper is one of the characters with regard to the nature of having care and attention. Helping can be manifested in the form of providing assistance. This assistance can also be in the form of material, energy, and thoughts. The helper character is represented by the role of Sherina in the film Adventures of Herina, when Sherina manages to help her kidnapped friend by sneaking into the car and entering the house of the kidnapper who is sleeping.

\section{Responsible}

Being responsible is one of the characters related to alertness and readiness to accept the burden in the form of a mandate or task that is given by being willing to accept any risks that occur. The responsible character is represented by the role of Rena in the film For Rena, when Rena always tries to protect her younger siblings from people who they fear will disturb her. Rena also always looks after her sister by telling her to be careful at all times. 


\section{Sincere spirit}

Sincere spirit is one of the characters with regard to sincerity, intentions accompanied by a like and willing attitude. Sincere-spirited characters are represented by the roles of Mr. Harfan Efendy Noor and Mrs. Muslimah in the film Laskar Pelangi, both actors, although in their social life they are known to be very poor people, they have never subsided in maintaining education in their village by building a school for their soul and sincerity. In addition, the two actors work hand in hand with sincerity to invite the children in their village to study at the school that was established.

The character with a sincere heart is also represented by the role of Delisa in the film Memorizing Delisa Prayers, namely when Delisa was hit by two major disasters, namely the earthquake and tsunami that hit her and secondly due to the earthquake, Delisa finally had to lose one of her legs. Apart from that, having a sincere spirit is depicted when the role of Delisa graciously accepts all the trials that befall her and admits that everything that befalls her is a trial from God. Sincerity is also related to the inner strength of surrender.

\section{Independent}

Independence is one of the characters related to growing self-confidence, namely not depending on others. In this case it is also related to the ability to do something with oneself. The independent character is represented by the role of Sherina in the film Petualangan Sherika, when Sherina herself can successfully save her friend from being kidnapped. In addition, the independent character is also represented by the actor Amik in the film Serdadu Kumbang, namely the actor Amik can complete his school education without financial assistance from his parents. School fees are obtained from the results of selling every day when they come home from school. Amik is also able to solve every problem he faces without the help of friends, other people, and let alone family or parents.

\section{Creative}

Creative is one of the characters with regard to the ability to create something or have creativity. Creativity involves the process of thinking carefully and critically so that you can find creative ideas, both in the form of techniques, strategies and in the form of created objects. The creative character is represented by the main character consisting of five children in the film Lima Elang, when the cast can win a group competition held at camp. The victory obtained by the main character team is the result of creative thinking together.

The types of character cast in Indonesian children's films are found to be in line with the concepts and objectives of character education launched by the Indonesian government since 2010 as an effort to develop students' personalities through quality educational activities and learning processes. Character is something related to psychological or psychological aspects. Character formation is a process that must be built and shaped in line with the physical development of students. In addition, character formation is also supported by situations and 
conditions or the environment (Erbas et al., 2021; Zavolzi, 2021; Suryasa et al., 2019).

Character can be formed in the process of education and learning. The formation of student character can be through various elements in learning. In addition to the direct guidance of a teacher, the interaction between students and their friends, the interaction of students with the school or classroom environment, is also more important through a learning process that is supported by media or learning materials. Therefore, the selection of media, learning resources, and learning materials must also be adjusted to the needs of students. Because, basically the purpose of learning is not only to fulfill the task of the teacher as a teacher and not just to convey subject matter to students, but it is important to shape the character of students.

Based on the statements of several teachers, Indonesian children's films are very appropriate and appropriate to be used as learning media as well as learning resources and learning materials. The stories or storylines presented in Indonesian children's films represent the world of children. Every scene, even all scenes in Indonesian children's films, is in harmony with the real-life experienced by students. Thus, scenes from Indonesian children's films make students feel as if they are exploring the story of the film they are watching.

Based on the previous statement, the character of the actors in Indonesian children's films can stimulate student development, both physically and the development of students' positive thinking, even physical development and thinking can take place simultaneously. Because, every character will be built and shaped by students both in the form of actions and thoughts, of course this is in line with the mind. In this case, that the embodiment of the student's character is processed through the mind.

Two basic findings are considered important in this section. First, the characters of the actors in Indonesian children's films are subjects that can be used by students as subjects as well as teachers who directly demonstrate a character, even though it is virtual because it is through fictional stories that are filmed, but these characters can be applied in real life by students in everyday life. -day. Second, the characters of the cast of Indonesian children's films describe several behavioral concepts that can be used by students as a way of understanding themselves and others in socializing and interacting. Both findings are closely related to psychology.

\section{The role of Indonesian children's films as media and learning resources or learning materials}

The essence of film as a learning medium can also be a medium to introduce Indonesian culture. In Indonesian children's films, they depict Indonesian activities and culture. Thus the coverage in these films can be of high value in developing students' character. The characters in question include; hone students' imagination and thinking power; directing students on how to deal with and solve a problem, educating students to learn independently and work together. 


\section{Students' ability in understanding the characters of Indonesian children's films}

Understanding the subject matter is a manifestation of cognitive skills. The main goal expected in language learning in general and Indonesian language learning in elementary schools, in particular, is the ability of students to integrate previous understanding with the understanding received through ongoing learning. The result of the process of integrating these two things is the ability of students to produce a variety of texts that can be retold through the students' own language. Based on research from the results of teaching several elementary school teachers using Indonesian children's films as a medium as well as learning resources and learning materials can develop students' language skills, especially in understanding the characters of Indonesian children's films. In the learning process, there are two things that students develop language skills, namely understanding context and understanding signs.

First, understanding the context relates to students' understanding of the conversations of the actors. The conversations carried out by the actors contain contexts that unite and form meaning. Thus, through the context that students understand, students will also get a complete set of understanding. In this case, the context that the student understands can be retold. Therefore, when students are able to retell, it shows that through films, especially Indonesian children's films which are used as media as well as learning resources and learning materials can stimulate and make it easier for students to understand what is being listened to.

Second, understand the cues regarding the expressions and movements made by the actors. The gesture or movement in question is sign language. Gestures or movements made by the actors are not mere gestures or movements. However, it has meaning and certainly requires a response for the other person to communicate. Gestures or movements made by Indonesian children's film actors provide a set of illustrations to provoke students to think so that they also require students to understand. This is called the signal context. Sign context relates to interaction and communication activities in which there is a process of speaking, but through gestures or body language.

Both language skills, especially students' understanding skills, relate to students' abilities and cognitive skills in relation to language. These two skills can be integrated, namely, the process of understanding, identifying, classifying, compiling, and producing a text. This is the main goal of the literacy aspect in terms of language skills. Therefore, the findings of this section are that the use of Indonesian children's films as media as well as learning resources and learning materials can develop students' abilities and skills in critical-creative thinking based on the understanding gained from Indonesian children's films.

The advantages of Indonesian children's films as media and learning resources or learning materials also have a positive impact on the development of student achievement, both in terms of psychological development, aspects of using technology as a medium, and also on aspects of language skills. Student achievement in question can be seen based on student learning outcomes in the form of values in the form of numbers presented in the form of percentages. The 
student learning outcomes obtained from several elementary school teachers are presented in the following table.

Table 1

Learning outcomes are seen based on psychological aspects

\begin{tabular}{llll}
\hline No. & Aspect Type & Score & $\%$ \\
\hline 1 & Student motivation & 105 & 100.0 \\
2 & Student interest & 89 & 84.76 \\
3 & Learning reaction & 93 & 88.57 \\
\hline
\end{tabular}

Table 2

Learning outcomes seen based on technological aspects

\begin{tabular}{clll}
\hline No. & Aspect Type & Score & $\%$ \\
\hline 1 & $\begin{array}{l}\text { Students' understanding of the role of } \\
\text { films as media, learning resources, }\end{array}$ & 84 & 78.78 \\
$\quad \begin{array}{l}\text { and learning materials } \\
2\end{array}$ & Making learning more effective & 95 & 89.84 \\
\hline
\end{tabular}

Table 3

Learning outcomes seen by language aspect

\begin{tabular}{llll}
\hline No. & Aspect Type & Score & $\%$ \\
\hline 1 & Students' ability to understand & 95 & 90.50 \\
2 & Students' ability to identify & 89 & 84.76 \\
3 & Students' ability to integrate and produce & 93 & 88.57 \\
\hline
\end{tabular}

The findings of this study are twofold, namely Indonesian children's films as a medium as well as a source of learning and learning materials can shape students' character and improve student achievement.

\section{Conclusion}

Based on the results and discussion, the respondents who were involved in the research and the majority of elementary school teachers considered that films that were used as media and learning resources or learning media should be applied and used frequently. In this case, the teacher is not only monotonous using manual media and makes books as learning resources or learning materials. In addition, many academics and curriculum designing teams suggested that films as media and learning resources or learning materials could not only be applied to elementary school students with certain subjects. However, it can also be applied to students at all levels, both junior high and high school, and can even be applied to students in college.

\section{Acknowledgments}

Our gratitude goes to our supervisor, Associate Professor Renata Meuter as Dean of the Faculty of Health from Queensland University of Technology Australia (QUT), who has provided in-depth observations of the deepening of this paper. Of course, 
we also thank the reviewers and editors of the LingCuRe Journal: Linguistics and Culture Review, for reviewing this paper. Indonesian children's films can be used as learning resources and learning media. Based on the research results, Indonesian children's films can develop the character of elementary school students, both psychologically, intellectually (critical thinking), and develop language skills. Therefore, Indonesian children's films deserve to be distributed in schools.

\section{References}

Abbott, J. (1994). Learning Makes Sense: Re-creating Education for a Changing Future: A Detailed Explanation of... Proposals for Structural Change in Schooling Based on the... Study of Effective Learning Strategies and a Better Appreciation of the Operation of the Brain. Education 2000.

Ahmad, J. (2012). English language teaching (ELT) and integration of media technology. Procedia-Social and Behavioral Sciences, 47, 924-929. https://doi.org/10.1016/j.sbspro.2012.06.758

Al Hamdani, D. (2016). The character education in Islamic education viewpoint. Jurnal Pendidikan Islam UIN Sunan Gunung Djati, 1(1), 98-109.

Arnheim, R. (1957). Film as Art: 50th anniversary printing. Univ of California Press.

Aslan, C. (2010). Opinions of postgraduate students in Turkish education programs on their academic self-efficacy. Journal of Mehmet Akif Ersoy University Faculty of Education , (19), 87-115.

Azzajjad, M. F., Tendrita, M., \& Ahmar, D. S. (2021). Effect of animation and review video making (arvima) in non-classical learning model on independent learning and students' learning outcome. Linguistics and Culture Review, 5(S3), 967-976. https: / / doi.org/ 10.21744/lingcure.v5nS3.1657

Barron, A. B., Hebets, E. A., Cleland, T. A., Fitzpatrick, C. L., Hauber, M. E., \& Stevens, J. R. (2015). Embracing multiple definitions of learning. Trends in neurosciences, 38(7), 405-407. https://doi.org/10.1016/j.tins.2015.04.008

Becker, G. S. (2009). Human capital: A theoretical and empirical analysis, with special reference to education. University of Chicago press.

Champoux, J. E. (2001). Animated films as a teaching resource. Journal of management education, 25(1), 79-100.

Corrigan, T., \& White, P. (2012). The film experience: An introduction. Macmillan.

Creswell, J. W., \& Clark, V. L. P. (2017). Designing and conducting mixed methods research. Sage publications.

De Houwer, J., Barnes-Holmes, D., \& Moors, A. (2013). What is learning? On the nature and merits of a functional definition of learning. Psychonomic bulletin \& review, 20(4), 631-642.

Dehkordi, A. G. (2011). The effect of instructional-aid films on learning of table tennis techniques. Procedia-Social and Behavioral Sciences, 15, 1656-1660. https: / / doi.org/10.1016/i.sbspro.2011.03.348

Desforges, C. (Ed.). (1995). Introduction to Teaching. Wiley-Blackwell.

Dewney, A., \& Ride, P. (2006). New Media Handbook (Media practice). London and New York: Routledge.

Diergarten, A. K., Möckel, T., Nieding, G., \& Ohler, P. (2017). The impact of media literacy on children's learning from films and hypermedia. Journal of Applied Developmental Psychology, 48, https://doi.org/10.1016/j.appdev.2016.11.007

33-41. 
Dorr, A., \& Brannon, C. (1992). Media education in American schools at the end of the twentieth century. In Medienkompetenz als Herausforderung an Schule und Bildung, Proceedings of Media Education Conference.

Ebbinghaus, H. (2013). Memory: A contribution to experimental psychology. Annals of neurosciences, 20(4), 155.

Echols, J. M., \& Shadily, H. (1995). Kamus Inggris-Indonesia: An EnglishIndonesian Dictionary. Jakarta Gramedia. Cetakan, 21.

Erbas, İsa, Çipuri, R., \& Joni, A. (2021). The impact of technology on teaching and teaching English to elementary school students. Linguistics and Culture Review, 5(S3), 1316-1336. https://doi.org/10.21744/lingcure.v5nS3.1815

Etsey, K., Smith, T. M., Gyamera, E., Koka, J., de Boer, J., Havi, E., \& Heyneman, S. P. (2009). Review of basic education quality in Ghana: Basic education in Ghana: Progress and problems. New York: The Mitchell Group for the United States Agency for International Development (USAID).

Farrant, J. S. (1980). Principles and practice of education (New Edition). Hong Kong: Longman.

Ferdiawan, E., \& Putra, W. E. (2013). Esq education for children character building based on phylosophy of Javaness in Indonesia. Procedia-Social and Behavioral Sciences, 106, 1096-1102. https://doi.org/10.1016/j.sbspro.2013.12.123

Flew, T. (2007). New media: An introduction. Oxford: Oxford University Press.

Gallardo-Echenique, E. E., Marqués-Molias, L., Bullen, M., \& Strijbos, J. W. (2015). Let's talk about digital learners in the digital era. International Review of Research in Open and Distributed Learning, 16(3), 156-187.

Giroux, H. A., \& Simon, R. I. (1989). Popular culture schooling and everyday life.

Gonçalves, A. D. S., De Araújo, V. L., Pereira, S., \& Moreira, I. X. (2017). Utilizing audiovisual media and learning motivation on student achievement of social department grade viii student fatumeta, Dili. International Research-Based Education Journal, 1(1).

Greenfield, P. M. (2014). Mind and media: The effects of television, video games, and computers. Psychology Press.

Hamidi, F., Kharamideh, Z. M., \& Ghorbandordinejad, F. (2011). Comparison of the training effects of interactive multimedia (CDs) and non-interactive media (films) on increasing learning speed, accuracy and memorization in biological science course. Procedia Computer Science, 3, 144-148. https://doi.org/10.1016/j.procs.2010.12.025

Heinich, R. (1996). Instructional media and technologies for learning. Simon \& Schuster Books For Young Readers.

Hobbs, R. (1998). Teaching with and about film and television: Integrating media literacy concepts into management education. Journal of Management Development.

Jarvis, P. (2007). Globalization, lifelong learning and the learning society: Sociological perspectives. Routledge.

Kozma, R. B. (1991). Learning with media. Review of educational research, 61(2), 179-211.

Lachman, S. J. (1997). Learning is a process: Toward an improved definition of learning. The Journal of psychology, 131(5), 477-480.

Lau, J., \& Chan, J. (2004). What is critical thinking? Retrieved May 25, 2016.

Locatis, C. N., \& Atkinson, F. D. (1990). Media and Technology for Education \& Training. Columbus, Ohio: Charles E. 
Marsh, C., \& Ortiz, G. (Eds.). (1997). Explorations in Theology and Film: An Introduction. Wiley-Blackwell.

Melby, C. S. (1994). Ghana primary school development.

Mincer, J. (1958). Investment in human capital and personal income distribution. Journal of political economy, 66(4), 281-302.

Mohan, T., McGregor, H., \& Strano, Z. (1992). Communicating!: Theory and practice. Harcourt Brace Jovanovich.

Nasution, S. N. (2018). Spirit of nationalism, education and moral religion: nation character building portrayed in Si Bulus-Bulus Si Rumbuk-Rumbuk written by Willem Iskander. International Journal of Linguistics, Literature and Culture, 5(1), 24-31. https://doi.org/10.21744/ijllc.v5n1.478

Nilsen, B., Albertalli, V., \& Albertalli, G. (2002). Introduction to Learning \& Teaching: Infants Through Elementary Age Children. Taylor \& Francis US.

Nimalathasan, B., \& Valeriu, B. (2010). Association Between Critical, Creative Thinking And Problem Solving In Accounting Researches: An Overview. Young Economists Journal/ Revista Tinerilor Economisti, 8(14).

Paul, R., \& Elder, L. (2011). Critical thinking: Competency standards essential for the cultivation of intellectual skills, part 3. Journal of Developmental Education, 35(2), 34.

Plass, J. L., \& Kaplan, U. (2016). Emotional design in digital media for learning. In Emotions, technology, design, and learning (pp. 131-161). Academic Press. https://doi.org/10.1016/B978-0-12-801856-9.00007-4

Radford, J., Bosanquet, P., Webster, R., \& Blatchford, P. (2015). Scaffolding learning for independence: Clarifying teacher and teaching assistant roles for children with special educational needs. Learning and Instruction, 36, 1-10. https: / / doi.org/10.1016/.j.learninstruc.2014.10.005

Rhodes, M. (1961). An analysis of creativity. The Phi delta kappan, 42(7), 305-310.

Ryan, K., \& Bohlin, K. E. (1999). Building character in schools: Practical ways to bring moral instruction to life. Jossey-Bass Inc., Publishers, 350 Sansome St., San Francisco, CA 94104.

Sabilah, F. (2016). Teaching techniques and instructional media in presenting intercultural awareness in English class of primary school students. International Journal of Linguistics, Literature and Culture, 2(4), 112121.

Retrieved

from

https: / /sloap.org/journals/index.php/ijllc/article/view/146

Schlecty, A. (2004). The art of teaching.

Siekanska, M., Bondar, Z. R., di Fronso, S., Blecharz, J., \& Bertollo, M. (2021). Integrating technology in psychological skills training for performance optimization in elite athletes: A systematic review. Psychology of Sport and Exercise, 102008. https://doi.org/10.1016/j.psychsport.2021.102008

Sivitanides, M., \& Shah, V. (2011). The era of digital activism. In Conference for Information Systems Applied Research (Vol. 4, No. 1842).

Sizer, T. (1992). School reform: What's missing. World Monitor, 5(11), 22-27.

Sternberg, R. J. (2009). Academic intelligence is not enough WICS: An expended model for effective practice in school and later in life. Innovations in Educational Psychology, 403.

Suryasa, I.W., Sudipa, I.N., Puspani, I.A.M., Netra, I.M. (2019). Translation procedure of happy emotion of english into indonesian in krșna text. Journal of Language Teaching and Research, 10(4), 738-746 
Thorndike, E. L. (1911). Animal intelligence; experimental studies, by Edward L. Thorndike.

Thring, A. S. (2001). Education, manpower and economic growth.

Tinajero, C., \& Paramo, M. F. (1998). Field dependence-independence and strategic learning. International Journal of Educational Research,29(3), 251-262. https: / / doi.org/10.1016/S0883-0355(98)00029-9

Van Rossum, E. J., \& Hamer, R. (2010). The meaning of learning and knowing. Rotterdam.

Yasumoto, S. (2014). Teaching and Learning in the Digital Era: A Case Study of Video-Conference Lectures from Japan to Australia. International Association for the Development of the Information Society.

Zavolzi, A. (2021). Translation professions involving mental capacity to learn lexical, structural, semantic, stylistic, pragmatic. Applied Translation, 15(1), 1827.

Retrieved

from

https: / /appliedtranslation.nyc/index.php/journal/article/view/1358 